\title{
O DISCURSO POÉTICO COMO UM "PROBLEMA LINGUÍSTICO” NAS NOTAS DE BENVENISTE: PERCURSOS METODOLÓGICOS PARA A ABORDAGEM DA SIGNIFICAÇÃO
}

\section{THE POETIC DISCOURSE AS A "LINGUISTIC PROBLEM” IN BENVENISTE'S NOTES: METHODOLOGICAL GUIDELINES FOR APPROACHING MEANING}

\author{
Carolina Knack \\ Universidade Federal do Rio Grande do Sul, UFRGS, Porto Alegre, RS, Brasil
}

\begin{abstract}
Resumo: Este estudo apresenta uma possibilidade de leitura das notas manuscritas de Émile Benveniste a respeito do discurso poético, notas estas que tomam a poesia de Baudelaire como corpus analítico. Resguardando a natureza inacabada e instável das reflexóes nelas inscritas, objetivamos explorar possíveis percursos metodológicos delineados pelo linguista para a abordagem do mecanismo da significaçâo do discurso poético. A leitura do conjunto das notas permite identificar apontamentos programáticos que delineiam não só categorias de análise, como também procedimentos metodológicos a serem empreendidos pelo linguista-analista, no cerne dos quais parece residir o exame das relaçōes referentes à escolha e à combinaçáo de palavras pelo poeta, o que leva Benveniste a postular que o linguista deve estudar uma "sintagmática particular" e "as relaçôes significantes assim obtidas".
\end{abstract}

Palavras-chave: discurso poético; sintagmatização; Baudelaire.

Abstract: This study presents a reading possibility of Émile Benveniste's handwritten notes regarding the poetic discourse, which take Baudelaire's poetry as an analytical corpus. Safeguarding the unfinished and unstable nature of the notes' reflections, we aim at exploring possible methodological guidelines designed by the linguist to approach the meaning mechanism of the poetic discourse. The reading of the set of notes allows to identify programmatic remarks which not only delineate categories of analysis, but also indicate methodological procedures to be undertaken by linguists-analysts, whose core seems to include the examination of the relations referring to the choice and the combination of words by the poet, which leads Benveniste to claim that linguists must study a "particular syntagmatic" and the "meaning relations obtained this way".

Keywords: poetic discourse; syntagmatization; Baudelaire. 


\section{Introduçáo}

Émile Benveniste, em seus já conhecidos textos publicados em Problemas de linguistica geral I e II (PLG I e PLG II), situa a significação na natureza da linguagem. De fato, é esse o ponto de vista a partir do qual o linguista interroga o funcionamento da linguagem, poeticamente anunciando que, "bem antes de servir para comunicar, a linguagem serve para viver", como escreve o autor em A forma e o sentido na linguagem (BENVENISTE, 2006a, p. 222).

Nesse artigo, Benveniste destaca a centralidade do "problema da significação", propondo a discussão das "noçôes gêmeas de sentido e de forma" no domínio da "linguagem dita ordinária, a linguagem comum, com exclusão expressa da linguagem poética, que tem suas próprias leis e suas funçóes próprias" (BENVENISTE, 2006a, p. 221). Porém, o linguista ressalva que tudo o que se esclarecer a respeito da linguagem ordinária poderá, de algum modo, contribuir para compreender a linguagem poética. Percorrendo outros escritos de Benveniste, constatamos que esta última recebe foco nas suas notas manuscritas sobre a "língua de Baudelaire". São essas notas que elegemos como objeto de investigação no presente estudo.

O conjunto dessas notas foi apresentado e transcrito por Chloé Laplantine, primeiramente em sua tese de doutorado (2008) e, em seguida, publicadas por ela no livro Baudelaire $(2011)^{1}$. Essas notas, de acordo com a pesquisadora, estão relacionadas a um artigo supostamente prometido por Benveniste - mas não publicado ou encontrado na condição de rascunho - para o número 12 da Revista Langages, de dezembro de 1968, número dirigido por Roland Barthes ${ }^{2}$.

Tais notas, sem dúvida, despertam a curiosidade de todos os que se interessam pela reflexão de Émile Benveniste. Elas estão depositadas

\footnotetext{
${ }^{1}$ A respeito dessa ediçấo em formato de livro, cujo título é Baudelaire, Fenoglio (2019c) aponta "contradiçóes", notadamente entre os arquivos e o ato editorial, dentre as quais o próprio fato de dar forma de livro (com autoria imputada à Benveniste, conforme se vê na capa) a um conjunto fragmentado de 386 fólios, pressupondo lisibilidade e coerência, sem anunciar tratarse de notas manuscritas de trabalho.

${ }^{2}$ Tal suposição está relacionada à existência de um manuscrito, aparentemente de 1967, segundo Laplantine (2008, p.140), em que Benveniste lista "artigos prometidos" e, dentre os tópicos, está "Linguagens (a língua de Baudelaire)". Porém, para Fenoglio (2019c, p. 208), apesar desse elo, a existência de tal lista náo permite tratar as notas de trabalho como rascunhos de um texto publicável, tampouco considerar que esse registro em lista seja o título de Benveniste a seu possível texto.
} 
no Departamento de Manuscritos da Biblioteca Nacional da França, em uma caixa ${ }^{3}$ com uma pasta azul com elástico, dentro da qual há outra pasta, de papelão cinza esverdeado, em cuja parte superior, à direta, está escrito "Baudelaire" - segundo Fenoglio (2019c), trata-se da caligrafia de Benveniste. Dentro desta, há outras 23 pastas menores, de cor cinza, nas quais foram organizadas as folhas manuscritas de Benveniste, "sem nenhum critério aparente", como constata Fenoglio (2019c, p. 204). Na sequência de tais pastas, há outra, laranja, vazia, em que está escrito (mas não por Benveniste) "Linguagem poética", e mais duas pastas vazias (uma vermelha e uma amarela).

Por que essas informaçóes descritivas são importantes e precisam ser pontuadas? Ora, elas indicam que "o dossiê arquivístico atual não representa certamente a organização inicial de Benveniste" (FENOGLIO, 2019c, p. 205), de tal modo que mergulhar nessas notas requer a adoçáo de um ponto de vista para a formulação de um percurso próprio de leitura e, consequentemente, de estudo, a partir dos caminhos abertos pelas pistas da escrita benvenistiana. $\mathrm{O}$ estudo que propomos deriva, justamente, da problemática - central para Benveniste - da significação, aqui relacionada a percursos metodológicos que possibilitam abordá-la.

Obviamente, não é como geneticistas ${ }^{4}$ que lemos as notas, mas como pesquisadores interessados na teorizaçáo benvenistiana, interesse que conjuga, de certa maneira, uma "curiosidade aleatória" - afinal, o que escreve Benveniste nas notas sobre o discurso poético a partir de seu olhar para a poesia de Baudelaire? - e uma "curiosidade orientada" - o que descobre

${ }^{3}$ A caixa está identificada como: BNF PAP., OR., DON 0429. Leia-se: Biblioteca Nacional da França, Papéis Orientais, Doação 0429.

${ }^{4}$ Fenoglio (2019a) explica que "o que interessa ao linguista-geneticista é enxergar um pouco melhor como se elabora a enunciaçáo escrita dentro de um processo de textualização”. O campo da genética textual busca, metodologicamente, constituir um "dossiê genético" de manuscritos, o qual passa a inventariar e classificar, a fim de analisar a (re)formulação textual no processo de escrita, percurso que pode receber diferentes ênfases a depender da orientação disciplinar do pesquisador. Para o geneticista-linguista, há um foco nas formas linguísticas de reformulação, contemplando operaçôes de acréscimo, supressão, substituição e deslocamento de formas. Quanto a esse último foco, Fenoglio destaca que ele assume uma dupla dimensão, pois envolve um "olhar linguístico sobre os vestígios do processo de escrita = recomposição enunciativa" e um "olhar do linguista sobre a elaboração do discurso linguístico e a formulação em ato de conceitos no qual se conjugam, de certa forma, genética textual, análise linguística enunciativa e análise do discurso" (FENOGLIO, 2019a, p. 33). Embora não com propósito genético, valemo-nos deste último ponto relativo à formulação de conceitos para explorar as notas manuscritas benvenistianas.

${ }^{5}$ As expressōes "curiosidade aleatória" e "curiosidade orientada" são tomadas de empréstimo 
Benveniste acerca do mecanismo de significação do discurso poético? $\mathrm{Ou}$, mais especificamente, que caminhos metodológicos Benveniste delineia para dar a ver o mecanismo da significação no discurso poético?

Ainda que não tenhamos um propósito genético, voltamos nosso olhar para "a elaboração do discurso e a formulação em ato de conceitos" (FENOGLIO, 2019a, p. 33), a fim de responder à última questão acima formulada. Trata-se, portanto, de uma reconstrução pessoal dos possíveis sentidos das notas, evidentemente lidas na sua imanência, com suas particularidades na condição de notas manuscritas, mas buscando-se pontos de contato com outros estudos de Émile Benveniste. Afinal, como orienta Fenoglio (2019c, p. 254), "Essas notas de trabalho podem ser citadas, cruzadas com outros escritos definitivos ou pré-textuais de Benveniste, mas não podem ser interpretadas fora de sua relação com os escritos do linguista”.

Quanto a essa relação com outros escritos do linguista, Adam (2012, tradução nossa) considera que "o estudo consagrado ao discurso poético é inseparável dos dois últimos grandes artigos de Benveniste: 'Semiologia da língua' (1969) e 'O aparelho formal da enunciação' (1970)”. Outros autores já exploraram essas relaçóes ${ }^{6}$.

Em nosso estudo, a partir da consideração da centralidade da significação, aventamos estabelecer relaçóes das notas sobre o discurso poético com outro artigo publicado em PLG II, aquele do qual partimos: A forma e o sentido na linguagem. Embora Benveniste delimite, nesse artigo, sua reflexão ao domínio da linguagem ordinária, ele também registra que "tudo o que se pode esclarecer no estudo da linguagem ordinária será de proveito, diretamente ou não, para a compreensão da linguagem poética também" (BENVENISTE, 2006a, p. 221-222). Assim, levando em conta nossa "curiosidade orientada", buscamos ver em que termos esse "proveito" pode se dar no que se refere aos possíveis caminhos metodológicos que Benveniste delineia para desvelar o mecanismo da significaçáo no discurso poético.

Para isso, dividimos o presente texto em mais três partes. Primeiro, apresentamos critérios para um ponto de partida de pesquisa em relação às notas; em seguida, considerando a questão central deste trabalho, exploramos pontos que julgamos salientes em alguns fólios, para, por fim, traçarmos algumas consideraçóes provisoriamente finais.

de Fenoglio (2019a, p. 33).

${ }^{6}$ No Brasil, destaca-se a tese de Vier (2016). 


\section{As notas manuscritas sobre o discurso poético: critérios para um ponto de partida}

A pesquisa com ou a partir de manuscritos requer uma série de consideraçóes preliminares, as quais dizem respeito tanto ao estatuto dos manuscritos sob análise quanto ao modo de abordá-los.

Fenoglio, renomada pesquisadora dos manuscritos benvenistianos, discute profundamente o habitus de escrita de Benveniste e o papel das diferentes etapas de elaboração dos textos do linguista. Essa experiência da autora permite-lhe afirmar que a materialidade transcrita e apresentada por Laplantine, o "dossiê Baudelaire", não configura um texto que possa ser lido de maneira linear e contínua. Segundo Fenoglio (2019c, p. 210-211), boa parte dos fólios "só trazem notas sem nenhuma redação ou com fragmentos de frases muito parciais", ou ainda "apenas algumas palavras"; "somente 35 folhas [das 386, conforme levantamento de Fenoglio] trazem fragmentos redigidos que podem, eventualmente, ter papel de rascunho, mas nós não encontramos nenhum rascunho passado a limpo", com exceção de um fólio datilografado ${ }^{7}$ cuja sequência está faltando.

Por isso, o dossiê sobre o discurso poético, conforme Fenoglio (2019c, p. 215), tem estatuto de notas de trabalho - "um conjunto de notas mais ou menos redigidas" -, as quais funcionam, para Benveniste, como um lugar não de esboço de pensamento, mas da própria inscrição de pensamento, que se cria à medida que é enunciado. O espaço-tempo das notas é, segundo a autora, uma instância inventiva:

Nas notas, Benveniste pensa-escreve: ele cria, inova ou se documenta, abre
seu "problema" para o mundo e apresenta suas observaçóes e suas surpresas.
No rascunho, ele formula, teoriza. Em outras palavras, nas notas, ele
pensa e rumina para circunscrever seu objeto e encontrar a expressáo de
seus conceitos; no rascunho, ele está no objetivo direto da escrita teórica,
expondo seu objeto para os outros linguistas e teóricos da linguagem. [...]
Benveniste procura, então, a expressáo mais apropriada em funçáo do leitor
de seu artigo. No espaço-tempo das notas, ele pensa; no espaço-tempo do
rascunho, ele escreve para a leitura dos outros (FENOGLIO, 2019a, p. 51,
grifos da autora).

A investigação de diferentes conjuntos de papéis de Benveniste relativos aos artigos dos PLG permitiu Fenoglio (2019a) categorizar as 
notas de trabalho, as quais podem configurar-se, de acordo com a autora, como (i) suporte de interrogação metodológica, (ii) suporte de memória, (iii) espaço de testagem de noçóes e, ainda, (iv) lugar de formação do pensamento teórico. Essa tipologia pode ser admitida também para o caso do dossiê sobre o discurso poético, mas com uma particularidade: não há "texto definitivo (nem rascunho, nem cópia passada a limpo, a fortiori nenhum texto publicado) que nos permitiria dizer o estado exato do avanço em relação ao que o escrupuloso Benveniste teria redigido" (FENOGLIO, 2019c, p. 93).

Debruçando-se sobre esse dossiê, Fenoglio (2019b, p. 93, grifo da autora) busca "ordenar a desordem arquivística dessas notas em duas rubricas": notas que realizam levantamento de dados a partir dos textos de Baudelaire e notas que realizam alguma reflexão relacionada a esses textos ou ao discurso poético de modo geral. As notas relativas ao levantamento de dados apresentam uma grande quantidade de exemplos advindos da poesia de Baudelaire. Não nos ocupamos de tais notas ${ }^{8}$. Interessa-nos as notas reflexivas e, no interior destas, aquelas que, de algum modo, buscam formular caminhos metodológicos para a abordagem, pelo linguista-analista, da significação no discurso poético de um modo geral.

Da leitura de conjunto destacamos, como ponto de partida para o exame mais detalhado, uma das poucas notas datadas por Benveniste: tratase do fólio 4, integrante do envelope 20. Reproduzimos, a seguir, tanto o fac-símile do manuscrito quanto a sua transcrição diplomática ${ }^{9}$, ambos provenientes do fascículo anexo à tese de Laplantine (2008).

8Para um exemplo acerca do uso das notas que Fenoglio (2009b) refere como "levantamento de dados", consultar Vier (2018). Nesse estudo, Vier interpreta a instauração de homologias, mostrando como "os perfumes, as cores e os sons se correspondem" em Baudelaire a partir dos elementos temáticos recortados por Benveniste.

${ }^{9} \mathrm{~A}$ transcrição diplomática reproduz datilograficamente o manuscrito, conservando, inclusive, a topografia da página. 


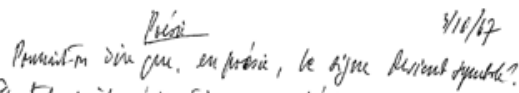

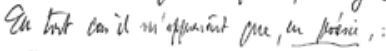

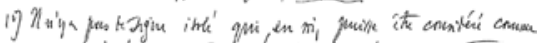

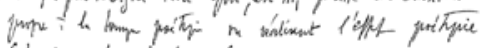

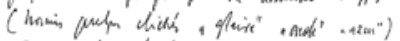

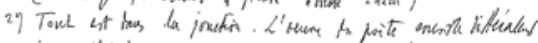

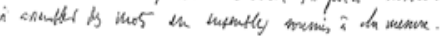

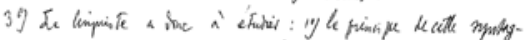

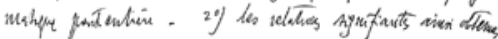

gy Prisije

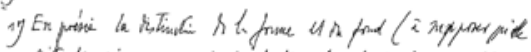

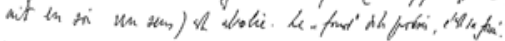

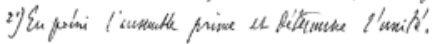

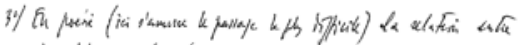

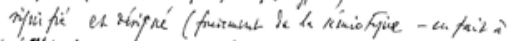

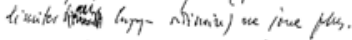

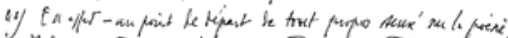

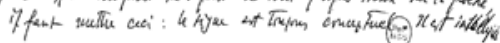

\section{BAUDELAIRE, 20, $\mathrm{f}^{\mathrm{D}} 4$}

Feuille blanche, $21 \times 27$, titre, date, debut du texte et deux derniers paragrapbes au stylo à bille blew, le reste au stylo à bille noir.

3/10/67

Posisis

Pourrait-on dire qque, en poésie, le signe devient symbole?

En tout cas, il m'apparait que, en noćsie,

17) Il n'y a pas de signe isolé qui, en soi, puisse ćtre considerd comme propere à la langue pośtique ou rálisant l'effet poctique ( hormis quelques clichés "glaive" $"$ onde" * azur $"$ )

$\left.2^{2}\right)$ Tout est dans la jonetion. L'auvre du poc̀te consiste littéralement à assembler des mots en ensembles soumis à la mesure.

35) Le linguiste a done à étudier : 19 ) le principe de cette syntagmatique particulière $2^{\circ}$ )les relations signifiantes ainsi obtenues.

$4^{*}$

\section{Principes:}

$1^{\circ}$ ) En possie la distinction de la forme et du fond (à supposer qu' elle ait en soi un sens) est abolic. Le $\alpha$ fond $x$ de la pośsic, c'est la $\alpha$ forme $m$.

$\left.2^{\circ}\right)$ En poésié l'ensemble prime et détermine l'unité

$3^{20}$ En poésie (ici s'amorce le pascage le plus difficile) la relation entre

signific et designe (fondement de la scmiotique - en fait à

limiter dans-ie langage ondinaire) ne joue plus.

$\left.4^{5}\right)$ En effet - au point de départ de tout propos sensé sur la poésie.

il faut mettre eeci : Ic signe est toujours conceptuel. II est intelligible.

Figura 1: Fac-símile do fólio 4 do envelope 20

Fonte: Laplantine (2008) 
Essa nota apresenta um pertinente encaminhamento metodológico dirigido ao fazer do linguista, notadamente os três primeiros itens listados por Benveniste. Por uma questão de espaço e recorte, os fólios não serão discutidos na sua integralidade. Assim, na sequência, para facilitar a leitura, optamos por traduzir e transcrever de modo linear ${ }^{10}$ o segmento em foco, utilizando marcas para sinalizar trecho sublinhado, riseado e <acréscimo na entrelinha> do manuscrito. Assinalamos com colchetes [...] os trechos suprimidos do fólio. Os segmentos traduzidos, também para facilitar a leitura, seráo, quando necessário, incorporados ao nosso texto, sempre identificados com número de envelope e fólio.

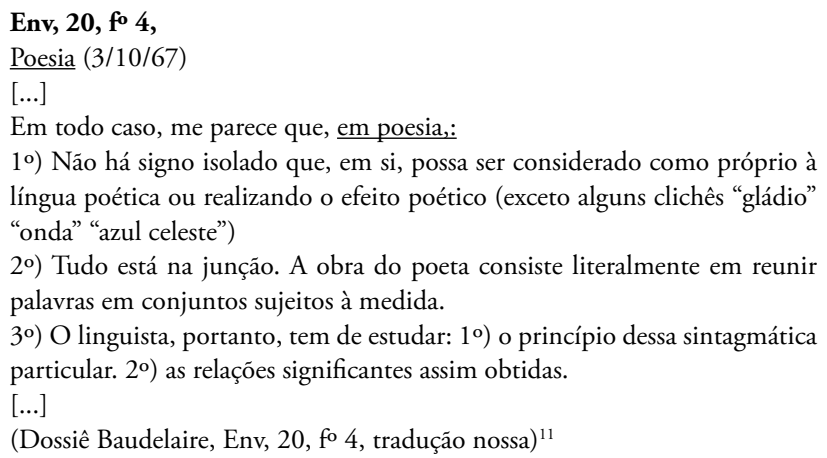

É pertinente observar, nesse segmento, o terceiro item listado: considerando que "não há signo isolado" e que "tudo está na junção", o que o linguista precisa estudar? Benveniste enumera: primeiro, o princípio da uma "sintagmática particular"; segundo, a significação assim construída pelo poeta.

Mas o que mais Benveniste nos diz a respeito disso? Há outras ponderaçóes, nos fólios, sobre esse possível caminho metodológico? Como bem pontua Fenoglio (2019c, p. 228), Benveniste sempre se preocupa com a metodologia, o que é "visível nos textos publicados". Especificamente quanto à literatura, em entrevista concedida por Benveniste a Guy Damur,

\footnotetext{
${ }^{10} \mathrm{~A}$ transcrição linearizada, embora utilize recursos gráficos para assinalar operaçôes de supressão, acréscimo etc., não segue a paginação e a translineação do manuscrito. O leitor poderá facilmente acessar o fac-símile dos manuscritos e sua transcrição diplomática no anexo à tese de Laplantine (2008), disponível em: <https://www.bibliotheque-numerique-paris8.fr/ document $/ 159650267 \#$ ? $\mathrm{c}=0 \& \mathrm{~m}=0 \& \mathrm{~s}=0 \& \mathrm{cv}=1>$.
}

${ }^{11}$ A partir deste ponto, não mais sinalizaremos com a expressão "tradução nossa". 
a qual constitui o texto Esta linguagem que faz história (PLG II), o linguista manifesta o quanto a literatura interessa à Linguística: "Imensamente", é o que afirma Benveniste. No entanto, ele pondera: "Mas este trabalho apenas começou. Não se pode dizer que o objeto de estudo, o método a ser empregado já estejam claramente definidos" (BENVENISTE, 2006b, p. 37, grifo nosso).

As tentativas de definir esse método comparecem nas notas manuscritas de Benveniste, cuja posição é "a do pesquisador que tateia" (FENOGLIO, 2019, p. 91, grifo da autora). Portanto, a partir do manuscrito anteriormente reproduzido, passamos a percorrer os demais fólios, a fim de, inferindo possíveis sentidos neles inscritos em potencial, estabelecer relaçóes no que se refere a esses "tateios metodológicos".

\section{O mecanismo da significaçáo no discurso poético: o que o linguista precisa estudar?}

A leitura dos manuscritos sobre o discurso poético revela uma constante: a interrogação de Benveniste acerca da significaçãa. Como o discurso poético significa? $\mathrm{Ou}$, mais particularmente, como a língua poética, "a língua de Baudelaire", significa? ${ }^{12}$ Em diferentes fólios, Benveniste anota que "O mecanismo de significação poética é diferente" (Env. 23, fo 35); "A língua poética deve ser considerada nela mesma e por ela mesma. Ela tem um outro modo de significação que a língua ordinária e ela deve receber um aparelho de definiçóes distintas. Ela chamará uma linguística diferente" (Env. 22, fo 51).

Essa "linguística diferente" requer categorias outras, outro "aparelho de definiçóes", e é essa tomada de consciência que se apresenta como uma grande dificuldade: "A principal dificuldade - uma dificuldade muito

\footnotetext{
${ }^{12}$ Nas notas, Benveniste emprega não apenas as expressões discurso poético e língua poética, mas também linguagem poética. Essa instabilidade, de acordo com Fenoglio (2019c), é constitutiva do estado de sua pesquisa, já que se tratam de registros em notas de trabalho. Cabe, no entanto, recuperar a interpretaçáo de Fenoglio (2019c, p. 231) acerca desses empregos: "'Linguagem' e 'discurso' aparecem sempre ao lado de 'poética(o)'. No campo do escrito e, mais precisamente, no campo da poesia escrita, linguagem e discurso são genéricos; a língua, por sua vez, vai demandar um sistema particular: há a 'língua de Baudelaire', como se pode imaginar que há a 'língua de Verlaine' ou a 'língua de Mallarmé', que Benveniste opóe à de Baudelaire”. Segundo a autora, não há discurso sem a passagem por uma língua particular que é, assim, mediação para a atualização da linguagem: "Benveniste escolheu a língua particular de Baudelaire para compreender $o$ discurso poético; material linguístico da linguagem poética” (FENOGLIO, 2019c, p. 231, grifos da autora).
} 
grande - do estudo <linguístico> da língua poética vem de que não se toma consciência da especificidade das categorias dessa forma de linguagem" (Env. 14 , fo 1$)$.

Essa dificuldade, aparentemente, pode estar relacionada ao fato de que "A poesia consiste primeiramente em reunir palavras [...]" (Env. 22, fo 42). Mas a palavra, para o poeta, tal como anota Benveniste, assume um estatuto outro, sobre o qual é preciso ainda teorizar ${ }^{13}$. Está posto, desse modo, um problema relativo à unidade no caso do discurso poético, uma preocupação de caráter teórico-metodológico, conforme as notas abaixo permitem constatar.

\section{Env. 21, fo $2^{14}$}

A teoria da língua poética está ainda por vir< <não existe ainda $>$ Este ensaio tem como objetivo acelerar um pouco o advento disso.

\section{Env. 22, fo 29}

[...]

A palavra é para o poeta uma coisa bem diferente do que é para o locutor. Há uma teoria da palavra na linguagem poética que está ainda para ser elaborada, mas que só começará a existir a partir do momento que tenhamos ab renunciado à noçáo de palavra concebida pela teoria da linguagem ordinária.

$[\ldots]$

\section{Env. 23, fo 32}

É toda uma nova teoria a constituir; aquela da língua de sentimento distinta da língua de utilidade e de comunicação sobre a qual é fundada nossa linguística atual.

$\mathrm{Na}$ língua de sentimento não é mais o signo que é a unidade admitida.

\section{Env. 22, fo 57}

[...]

E o poeta? O poeta combina palavras. As palavras são o material sobre o qual ele trabalha. É, entáo, evidente que, tornadas material do poeta, as palavras não podem mais ser os "signos" do uso comum. Cada poeta utiliza à sua maneira esse material. [...]

\section{Bédouret-Larraburu e Laplantine (2015, p. 14, tradução nossa)}

\footnotetext{
${ }^{13} \mathrm{~A}$ complexa reflexão a respeito da palavra como unidade de significação não se esgota nesses poucos fólios aqui mencionados. Por uma questão de recorte, limitamo-nos a apontar a singularidade do estatuto que esse termo assumiria em uma programática "teoria da língua poética" (Env. 21, fo 2).

${ }^{14}$ Tradução presente em Fenoglio (2019c, p. 228).
} 
afirmam que, de fato, a literatura "transforma a língua e desloca as categorias de sua análise". Desse modo, ainda que Benveniste evoque, nas notas, termos assemelhados aos de sua linguística geral para ir dando forma a seu "aparelho de definiçóes" em uma "nova linguística" - que enfoca a "língua poética" -, tais termos passam a se revestir de valores novos. Isso porque o que está em questão "[...] não é mais a linguagem ordinária, ainda que formada das mesmas unidades, mas um sistema próprio, agenciado segundo suas próprias categorias e funçôes" (Env.8, fo2).

É o caso do termo palavra: "A língua poética não reúne palavrasconceito, mas palavras-imagem. [...] Toda linguística da poesia deverá proceder da noção de imagem e a conceitualizar para daí extrair um novo sistema de significaçôes" (Env. 19, fo 2). Mas como se constrói esse sistema de significações? A palavra-imagem desperta e suscita emoção (Env.8, fo9), pois a língua poética é a "língua de sentimento" (Env. 22, fo 57, sublinhado do autor). ${ }^{15} \mathrm{E}$ como o poeta opera para construir discursivamente a emoção? Observemos o que nos dizem os segmentos a seguir:

\begin{abstract}
Env. 22, fo 52
$[\ldots]$

O esforço do poeta repousa sobre as palavras, e as palavras são o que atrai a atenção do leitor ou do ouvinte. As palavras estão aí como um objeto em si: sobre elas convergem os olhares, é elas que o espírito interroga; as contemplamos por elas mesmas. Elas formam um discurso todo particular, rítmico sem dúvida, mas antes criador de uma significação específica. É dessa significaçâo que nos esforçamos para extrair o princípio.
\end{abstract}

\title{
Env. 22, fo 58
}

$[\ldots]$

O problema será, portanto, ver como a língua do poeta é língua, como ela efetua, sem jamais se confundir com o instrumento comum a todos, essa missão de verdade e de revelação que é sua função. Como as combinaçôes de palavras podem produzir esse resultado?

$[\ldots]$

\section{Env. 22, fo 2}

Como ele obtém essa "denotação de emoção"?

Por seus agenciamentos particulares de palavras, que continuam signos, mas

\footnotetext{
15 Vier (2016) apresenta uma leitura acerca desse "novo sistema de significaçóes". Ao percorrer as notas, a autora compreende que a palavra funciona como ícone (termo empregado por Benveniste nas notas) para significar: de palavra-conceito (que significa a ideia) passa à palavraimagem (que iconiza a emoção). Por isso, "a iconia - o ato de iconizar a emoçáo - é o princípio do funcionamento do poema. Esse funcionamento deve ser pensado, então, a partir do iconizante - a imagem - e do iconizado - a emoçáo" (VIER, 2016, p. 150, grifos da autora).
} 
valorizadas de modo novo por alianças novas.

$[\ldots]$

Como entâo se realiza essa linguagem? Pelas combinações de palavras, próprias a produzir esse efeito e a tomadas <como signos> no léxico da língua, mas ag escolhidas e agenciadas de modo novo. [...

$\mathrm{Na}$ busca pela explicação do princípio da significação específica do discurso poético, Benveniste depara-se com "a língua do poeta", que ainda é língua, mas não se confunde com aquilo que é comum a todos os falantes - as palavras com as quais o poeta opera são, de algum modo, os signos tomados no léxico da língua; porém, escolhidas e agenciadas pelo poeta, produzem "um discurso todo particular" (Env.22, fo 52).

Reencontramos, aqui, um raciocínio de certo modo semelhante ao que vemos Benveniste expor em A forma e o sentido na linguagem (2006b, p. 229), quando se interroga sobre como a lingua significa e propóe distinguir "duas espécies e dois domínios do sentido e da forma", o semiótico e o semântico, "ainda que, eis ainda aí um dos paradoxos da linguagem, sejam os mesmos elementos que se encontrem em uma e outra parte, dotados, no entanto, de estatutos diferentes". No semiótico, cuja função é a de significar, a unidade é o signo; no semântico, cuja função é a de comunicar, a unidade é a palavra. Do domínio semiótico ao domínio semântico, há, como diz Benveniste (2006a, p. 229), "uma mudança radical de perspectiva: todas as noçóes que passamos em revista retornam, mas outras e para entrar em relaçóes novas".

Em alguma medida, podemos dizer que esse raciocínio paradoxal comparece nas notas: noções teórico-metodológicas propostas quando da discussão acerca do modo como a língua significa no uso ordinário retornam, mas "outras" e em relaçóes novas, porque reconfiguradas para refletir acerca do modo como a língua significa no uso poético.

Uma dessas noções parece estar relacionada à operação de escolha e agenciamento de palavras. Benveniste, no último fólio que anteriormente destacamos (Env. 22, fo 2), aponta que a "denotaçáo de emoção" se dá por meio de "agenciamentos particulares de palavras", "pelas combinaçóes de palavras", como reafirma na mesma nota, palavras estas que são escolhidas e "valorizadas de modo novo" em "alianças novas".

É interessante perceber como esse procedimento ligado à escolha e ao agenciamento de palavras é reiteradamente registrado por Benveniste nas notas, como atestam os poucos segmentos reproduzidos a seguir: 


\section{Env. 22, fo 13}

[...] palavras que te <o poeta $>$ escolheu, que ele elegeu entre todas, as junçôes que ele opera deliberadamente entre essas palavras compóem um certo retrato da visão que ele carrega consigo, da emoção que nele habita. $[\ldots]$

\section{Env. 22, fo 28}

[...]

Mais uma vez, o poeta opera com palavras. A relação entre a escolha e o agenciamento das palavras, de um lado, o 'sentido' da expressão, do verso, do poema, de outro, tal é o problema linguístico, um problema de relaçôes.

\section{Env. 22, fo 33}

[...] Entre o 'sentido' <individual> dessas palavras e o 'sentido' que elas são encarregadas de realizar por sua junção, a distância pode ser grande. [...]

\section{Env. 23, fo 30}

[...]

É, portanto, $1^{\circ}$ ) a escolha $2^{\circ}$ ) a junção que fazem as 'palavras poéticas'.

$[\ldots]$

Essas formulaçóes mostram, sem dúvida, o que Fenoglio (2019b, p. 93, grifo da autora) denomina como ruminação na escrita do linguista: "O conteúdo de uma nota é retomado em vários fólios, que testam terminologias ou aproximaçôes, que retomam incansavelmente a mesma ideia, sob outros enunciados". De acordo com a pesquisadora, a ruminação revela tanto uma hesitação na busca por uma formulação adequada acerca do "problema" quanto uma insistência do pensamento que abre os caminhos para isso.

Nesse movimento de hesitação e insistência, vemos sobressair-se a constataçáo acerca do procedimento operado pelo poeta: ele escolhe, elege palavras; ele deliberadamente as junta, coloca-as em alianças. Logo, a significação específica do discurso poético se instancia como um "problema linguístico" porque "problema de relaçôes": "a relaçấo entre a escolha e o agenciamento das palavras, de um lado, o 'sentido' da expressão, do verso, do poema, de outro" (Env. 22, fo 28). Por isso, conclui Benveniste: "É, portanto, $1^{\circ}$ ) a escolha $2^{\circ}$ ) a junção que fazem as 'palavras poéticas'” (Env. 23, fo 24).

É possível propor, então, pontos de contato entre essas anotaçôes e as reflexôes relativas à linguagem ordinária presentes em $A$ forma e o sentido na 
linguagem (BENVENISTE, 2006a). Ao buscar elucidar como se constrói o "sentido" no domínio semântico, o da língua em emprego pelo locutor, Benveniste detém-se sobre "o agenciamento sintagmático":

O sentido da frase é de fato a idéia que ela exprime; este sentimento se realiza formalmente na língua pela escolha, pelo agenciamento de palavras, por sua organização sintática, pela ação que elas exercem umas sobre as outras. Tudo é dominado pela condição do sintagma, pela ligação entre os elementos do enunciado destinado a transmitir um sentido dado, numa circunstância dada. Uma frase participa sempre do "aqui e agora"; algumas unidades de discurso são aí unidas para traduzir uma certa ideia interessante, um certo presente de um certo locutor. [...] Que a idéia só encontre forma num agenciamento sintagmático, esta é uma condição primeira, inerente à linguagem (BENVENISTE, 2006a, p. 230-231, grifo do autor).

A semelhança vocabular entre esse trecho e as notas sobre o discurso poético, à primeira vista, impressiona. Porém, é preciso estar ciente de que Benveniste emprega, por vezes, "termos que, apesar de idênticos do ponto de vista da expressão, são completamente distintos quanto a seu significado (uso homonímico)" ou, ainda, que "existem termos com expressóes diferentes, mas que têm o mesmo conceito (uso sinonímico)" (FLORES, 2013, p. 34). Consequentemente, as aproximaçóes entre as notas e o que está proposto no artigo é de nossa inteira responsabilidade.

O fato é que, se a ideia só encontra forma num agenciamento sintagmático e esta é uma "condição primeira, inerente à linguagem", então o agenciamento sintagmático é ponto nodal para a instauração da significação tanto no discurso ordinário quanto no discurso poético.

Nessa direção, apontamentos gerais relativos a esse procedimento no âmbito do discurso ordinário são extensíveis ao discurso poético. Por exemplo, o princípio de que "o sentido de uma frase é outra coisa diferente do sentido das palavras que a compóem" (BENVENISTE, 2006a, p. 231). Por isso, "Ainda que se compreenda o sentido individual das palavras, podese muito bem, fora da circunstância, não compreender o sentido que resulta da junção das palavras [...]" (BENVENISTE, 2006a, p. 231), pois "É como consequência de sua coaptaçáo que as palavras contraem valores que em si mesmas elas náo possuíam e que são até mesmo contraditórios com aqueles que elas possuem em outros lugares" (BENVENISTE, 2006a, p. 232).

Tal é a natureza da observação de Benveniste também quanto ao discurso poético, em fólio já anteriormente reproduzido: "Entre o 'sentido' $<$ individual> dessas palavras e o 'sentido' que elas sáo encarregadas de realizar pela sua junção, a distância pode ser grande” (Env. 22, fo 33). Então, há, 
evidentemente, o princípio comum de que o sentido resultante da junção difere daquele individual das palavras.

No entanto, em vez da ideia, o que está em jogo no discurso poético é, segundo as notas de Benveniste, a emoção ${ }^{16}$.

\section{Env. 22, fo 47}

Com as palavras, que têm um "sentido", comunicar uma emoçăo, traduzir uma sensação. O poeta deve, portanto, inventar associaçóes de palavras e, antes de mais nada, escolher essas palavras de tal maneira que sua "mensagem" seja ela mesma vetor de alguma outra coisa, que a ultrapassa. $[\ldots]$

\section{Env. 23, fo 13}

Cada experiência é necessariamente particular e única.

Ela requer a cada vez uma invençáo da escritura, um tratamento de palavras.

Se estamos, no poético, diante de uma invenção da escritura, há aí especificidades quanto ao agenciamento sintagmático. Em $A$ forma o sentido na linguagem, Benveniste (2006, p. 232) afirma que, indo para além das palavras, "a ideia deve sofrer a restrição de leis de seu agenciamento" e que há, quanto a isso, "necessariamente uma mistura sutil de liberdade no enunciado da idéia e de restrição na forma deste enunciado, que é a condição de toda atualizaçáo da linguagem". Sem dúvida, eis aí uma condição de toda atualização da linguagem. Porém, parece-nos que, quando se trata do discurso poético, não estamos mais diante de uma mistura sutil de liberdade e de restriçáo, mas de uma extrema liberdade. Tanto é que, como lindamente escreve Benveniste, nas notas, "a poesia é a poesia mais um certo poeta, já que cada poeta tem sua língua poética” (Env. 21, fo 2) ${ }^{17}$.

A demarcação dessa singularidade não é novidade nas reflexões de Benveniste:

\footnotetext{
${ }^{16} \mathrm{Em}$ relação a isso, é pertinente observar, nas notas, a formulação de reflexóes acerca de intentado conceitual (intentado-ideia) e de intentado emocional (intentado-afetivo), par conceitual em relação ao qual se pode ainda problematizar a referência, ponto também registrado por Benveniste nas notas. Ou seja, o recorte que aqui apresentamos não passa de um fio na trama tecida pelo linguista.

${ }^{17}$ Fenoglio (2019c, p. 219, grifo da autora) assinala que "essa nota, em sua precipitação, diz expressamente que houve escolha por Baudelaire, como de um 'certo poeta' desenvolvendo uma 'língua poética' particular, expressão singular que tem seu próprio sistema de funcionamento e que desempenha o papel de material de estudo para compreensão do discurso poético como fato linguístico."
} 
Ora, ele diz exatamente que a frase é um "acontecimento que desaparece" ou que "dizer bom dia todos os dias a alguém é, cada vez, uma reinvençáo". Se "todo homem inventa sua língua e a inventa durante toda sua vida", como diz ainda, o poeta, por sua vez, leva essa faculdade ao extremo e faz seu sistema de escrita. É esse funcionamento extremo da poesia que Benveniste quer linguisticamente expor (FENOGLIO, 2019c, p. 255).

A explicação linguística desse funcionamento requer, segundo nosso entendimento, a consideração da noção de "agenciamento sintagmático". Ono (2007) explica que essa noção, no artigo $A$ forma e o sentido na linguagem, é expressa tanto pelo termo "agenciamento das palavras", quanto pelo termo "agenciamento sintagmático" ou, ainda, pelo termo "organização sintática”. A autora destaca que Benveniste cria, inclusive, um neologismo a fim de esclarecer esse movimento: a "sintagmação". Esse termo, traduzido por "sintagmatização", na versão brasileira, diz respeito a uma operação que não só cria a forma da frase pela combinação das palavras, mas também cria o seu sentido. Ou seja, a sintagmatização é, de acordo com Ono (2007), uma açáo que implica toda uma operaçáo semântica e que se instaura como um "movimento negociador entre as palavras".

Então, se cada poeta tem "sua" língua poética, isso significa que, embora haja, como "condição de toda atualização da linguagem" (BENVENISTE, 2006a, p. 232), a exigência de um agenciamento sintagmático, este não está submetido às mesmas "leis" de agenciamento da língua "comum a todos", tal como ilustra a nota a seguir:

\footnotetext{
Env. 22, fo 58

[...]

O problema será, portanto, ver como a língua do poeta é língua, como ela efetua, sem jamais se confundir com o instrumento comum a todos, essa missão de verdade e de revelação que é sua função. Como as combinaçôes de palavras podem produzir esse resultado?

A coerência sintática do discurso poético em Baudelaire não deve nos induzir a pensar que a língua poética tem as mesmas exigências de código que a língua usual. Não é nada disso. Que o vocabulário do poeta se encontre todo no seio da língua usual não significa nada, uma vez que esse vocabulário está assujeitado a fins totalmente diferentes e utilizado pelas propriedades às quais a linguagem ordinária é indiferente ou mesmo opp hostil [...].
}

A singularidade do funcionamento do discurso poético, tanto em termos sintáticos quanto lexicais - aspectos destacados na nota anterior -, parece levar Benveniste a reiterar a necessidade de considerar categorias 
distintas para tratar desse discurso, dentre as quais uma "sintagmática poemática”. É o que registra na nota a seguir:

\section{Env. 22, fo 62}

[...]

O princípio é que cada palavra poética tem seu paradigma poético poemático; este é constituído pelo conjunto das possibilidades de rima que a palavra em questáo comporta. Esse paradigma, nós o dizemos poemático porque ele é dado na estrutura do poema e porque ele é exigido por essa estrutura. Ele vale para a parte final do verso somente.

Haverá, paralelamente, uma sintagmática poemática a reconhecer: é aquela que é comandada teternninata pela medida do verso (proibição de exceder um número dado de sílabas, divisões internas etc.)

$[\ldots]$

O qualificador poemática(o) é pensado por Benveniste, primeiro, em relação a "paradigma" - haveria um "paradigma poemático" constituído por um conjunto de possibilidades - cuja descrição como poemático decorre de ser "dado na estrutura do poema", "exigido por essa estrutura" (Env. 22, fo 62). O mesmo se aplica ao que nomeia como "sintagmática poemática”, que resta "a reconhecer" a cada poema particular.

Esta última exige, por isso, uma concepção distinta de sintagma, uma organização livre de palavras sem limites previamente dados: "[...] Em poesia, o sintagma se amplia para além de suas timensóes <limites> gramaticais; ele abrange a comparação, o entorno mais largo, às vezes a rima [...]" (Env. 12, fo 6). Benveniste, aliás, propóe renomear o sintagma, hipotetizando novos termos para isso: "symphorie <sympathème?> ou symphronie". Segundo Laplantine (2009, p. 36, tradução nossa), "Benveniste propóe o conceito de 'sympathème' como crítica do conceito de sintagma, de sua limitação" para o discurso poético ${ }^{18}$. Para a autora, tal termo está em relação, nas notas, com "pathème", "a emoção", em uma analogia com outros termos próprios ao campo linguístico, como "phonème", "lexème".

Esse exercício de invenção terminológica denuncia que outras tantas categorias devem ser repensadas:

\section{Env.22, fo 67}

\footnotetext{
${ }^{18}$ Em sua tese, Laplantine (2008) apresenta interpretações para os termos aqui referidos, ligando-os a uma dimensão relativa à "leitura subjetivante", à "leitura poética”, uma vez que as associaçóes são feitas por quem lê o poema. Se, de um lado, tais termos implicam uma teoria da escritura poética, de outro, implicam uma teoria da leitura. Em que termos tal teoria da leitura se instancia? Eis uma questão a se pensar.
} 
$[\ldots]$

(Eu penso, no fim das contas, que a análise da língua poética exige, em toda a extensão do domínio linguístico, categorias distintas. Não se deveria ser tâo radical. Será necessário, portanto, propor: uma fonemática poética, uma sintaxe poética, uma gramática poética, uma lexicologia poética.)

$[\ldots]$

A constatação de "categorias distintas" necessárias a uma "teoria da língua poética” (Env. 21, fo2) - das quais apenas algumas foram aqui retomadas - vai a par, nas notas, com o levantamento de dados oriundos da poesia de Baudelaire, ligados à "análise descritiva do poema" feita por Benveniste (Env. 23, fo 31, sublinhado do autor). O linguista, porém, registra: "O que eu tento descobrir é o modo de funcionamento da língua poética” (Env. 23, fo31, sublinhado do autor).

Assim, por meio desse duplo movimento, de teorizaçáo e de análise ${ }^{19}$, Benveniste parece constatar que os elementos situados no cerne do funcionamento do discurso poético estão ligados à invenção de palavras e sua junção ou agrupamento, do que resulta um sentido sempre a descobrir. Tal é a consideração da nota a seguir, redigida em tom "conclusivo":

\section{Env. 22, fo 54}

[...]

Nós distinguimos, portanto, três planos sucessivos no discurso poético:

1) o primeiro - primeiro em todos os aspectos - é aquele da invençấo das palavras e de seu agrupamento de modo novo;

2) das palavras assim juntas nasce um "sentido poético" que deve a cada vez ser descoberto, que pode ficar mesmo incerto ou obscuro, mas que náo está menos lá;

3) ao mesmo tempo, esse "sentido poético" irradia uma emoção, patética ${ }^{20}$ ou estética, ligada à forma sonora do verso.

Esses planos sucessivos intervêm, aparentemente, na formulação por Benveniste, em diferentes notas, de caminhos metodológicos a serem empreendidos pelo linguista-analista para desvelar o referido funcionamento de uma língua poética de um poeta. Reencontramos, enfim, o ponto do qual partimos neste estudo: o fólio 4 do envelope 20, no qual Benveniste enumera,

${ }^{19} \mathrm{Em}$ termos analíticos, é pertinente observar os dados que Benveniste recupera da poesia de Baudelaire, nos quais examina, por exemplo, relaçôes de coordenação e justaposição (como fo1 e fo8 do envelope 20).

${ }^{20} \mathrm{O}$ termo empregado por Benveniste, na nota em questão, é pathétique. Esse termo está em relação com outros utilizados pelo linguista, em outras notas, como pathème e pathématique, os quais se referem à dimensão emocional da linguagem (LAPLANTINE, 2008). 
primeiro, que "não há signo isolado que, em si, possa ser considerado como próprio à língua poética ou realizando o efeito poético"; segundo, que "tudo está na junção", na reuniáo de palavras operada pelo poeta; e terceiro, que, diante dessas constataçóes, "O linguista, portanto, tem que estudar: $1^{\circ}$ ) o princípio dessa sintagmática particular. $2^{\circ}$ ) as relaçóes significantes assim obtidas" (Env. 20, fo 4).

É interessante observar que, em diferentes fólios, há elaboração escritural que busca circunscrever, de algum modo, objeto e método quanto ao estudo do discurso poético. Essa elaboração nos permite visualizar uma espécie de trânsito entre uma especificidade metodológica - relativa ao caminho traçado no fólio 4 do envelope 20 , focado no estudo da "sintagmática particular" - e uma generalidade metodológica - relativa à consideração de outros possíveis procedimentos, não delimitados de antemão, para o estudo de um discurso poético particular. Isso nos conduz a compreender que a investigação de uma "sintagmática particular" é um desses procedimentos não o único, mas um dos mais relevantes.

\begin{abstract}
Env. 22, fo 49
[...]

Importa, portanto, conhecer esse mundo da realidade vivida pelo poeta para apreender o mecanismo da significação na língua poética.

A primeira tarefa será, portanto, descrever o 'universo da experiência' em Baudelaire. [Enumerar os temas principais dessa descrição.]

Em seguida, é necessário ver de que maneira, por quais procedimentos formais as palavras do discurso poético se relacionam a esse universo. A abordagem é totalmente diferente daquela que a natureza do signo impóe no funcionamento da linguagem ordinária.
\end{abstract}

Env. 14, fo $3^{21}$

Articulação do estudo [...] É preciso, portanto, apreender e trazer à luz esses temas maiores, traídos ou enunciados por certos termos-chaves [...] Então vem o estudo dos procedimentos pelos quais o poeta organiza/assegura a expressão disso que ele quer comunicar, isto é, de sua emoção.

Eis, nesses fólios, "tateios metodológicos" de Benveniste, os quais entendemos que revelam o que Fenoglio (2019a) considera "processos programáticos", marcados por traços específicos da escrita de Benveniste. Chama a atenção, por exemplo, o emprego reiterado do operador linguístico "portanto", seguido de verbo no infinitivo, nos dois fólios anteriores "Importa, portanto, conhecer [...]"; "A primeira tarefa será, portanto,

${ }^{21}$ Tradução presente em Fenoglio (2019c, p. 229). 
descrever [...]" (Env. 22, fo 49); "É preciso, portanto, apreender [...]" (Env. 14, fo 3). A esse propósito, Fenoglio (2019a, p. 59) constatou, ao analisar a gênese do artigo $A$ linguagem e a experiência humana, que "enunciar um programa de operaçôes metodológicas para utilização de infinitivos marcando a injunção" é um traço da escrita de Benveniste. É o que vemos também nas notas. Nestas, há uma busca pela delimitação de "tarefas, métodos, pontos de vista sobre um mesmo objeto linguístico com um léxico apropriado" (FENOGLIO, 2019a, p. 59), o que vem expresso pelos substantivos "tarefa" e "abordagem", por exemplo. De fato, trata-se de uma textualidade em elaboraçấo.

Evidentemente, nosso objetivo não consistiu em esmiuçar os traços específicos da escrita de Benveniste, mas em explorar pontos que julgamos relevantes quanto a um possível caminho metodológico inscrito em potencial nas notas sobre o discurso poético. Nosso percurso permitiu identificar apontamentos programáticos que delineiam não só categorias de análise, como também procedimentos a serem empreendidos pelo linguista-analista, dentre os quais parece residir o exame das relaçóes referentes à escolha $\mathrm{e}$ à combinaçáo de palavras pelo poeta, o que leva Benveniste a postular que o linguista deve estudar uma "sintagmática particular" e "as relaçôes significantes assim obtidas". Sem dúvida, trata-se de um ponto nodal do funcionamento do discurso poético.

\section{Consideraçôes finais}

Tais consideraçôes (ditas) finais, são, ao contrário, um novo ponto de partida. Como afirmam Bédouret-Larraburu e Laplantine (2015, p. 18, tradução nossa), "Os manuscritos sobre a linguagem poética, assim como as Últimas Aulas, relançaram a atualidade de Benveniste”. Enveredar por esses caminhos é, pois, necessário ao pesquisador interessado nas reflexôes benvenistianas. De nossa parte, escolhemos mergulhar nas notas manuscritas sobre o discurso poético e o fizemos a partir de uma "curiosidade aleatória" - afinal, o que escreve Benveniste nas notas sobre o discurso poético a partir de seu olhar para a poesia de Baudelaire? - e uma "curiosidade orientada" - o que descobre Benveniste acerca do mecanismo de significą̧ão do discurso poético? $\mathrm{Ou}$, mais especificamente, que caminhos metodologicos Benveniste delineia para dar a ver o mecanismo da significą̧ão no discurso poético?

Com o propósito de responder a essa última questáo, voltamo-nos para o plano conceitual dessas notas e observamos "a formulação em ato 
de conceitos", para, de algum modo, "compreender a construção de um discurso teórico e a elaboração de noçóes e conceitos" (FENOGLIO, 2019, p. 37) quanto aos "tateios metodológicos" de Benveniste. Cabe reiterar: tal percurso considera a natureza instável e não acabada das notas de trabalho e propóe, primeiro, lê-las na sua imanência - leitura, aliás, não linear - e, em seguida, relacioná-las com outros escritos de Benveniste.

Percebemos, de fato, que "o poema questiona e torna incertas as evidências da linguagem, traz um risco teórico para seus autores” (LAPLANTINE, 2013, p. 224). No entanto, quanto ao que vemos nas notas sobre o discurso poético, concordamos com Fenoglio (2019c, p. 254): "o interesse de Benveniste pelo literário não é, ele próprio, literário". O discurso poético instancia-se, para Benveniste, como um problema linguístico, cuja abordagem, ainda que especifique uma forma e um funcionamento de discurso, "não contradiz sua teoria geral do discurso" (FENOGLIO, 2019c, p. 255).

Tanto é que, em nosso percurso de leitura, visualizamos pontos de contato entre as reflexóes propostas por Benveniste em A forma o sentido na linguagem (2006a) e aquilo que ele pensa nas notas. Nestas, pareceu "saltar aos nossos olhos" o ponto relativo ao agenciamento sintagmático, afinal, em muitas das anotaçôes, ele registra que são os "agenciamentos particulares de palavras", escolhidas e reunidas pelo poeta, que instauram a significação específica do discurso poético. Como cada poeta utiliza à sua maneira esse material, resta reconhecer, a cada vez, uma "sintagmática poemática", que é também ela singular a cada poesia. Nessa direçáo, Benveniste propóe que o linguista precisa estudar "o princípio dessa sintagmática particular" e "as relaçôes significantes assim obtidas” (env. 20, fo 4).

Assim, se "a ideia só encontre[a] forma num agenciamento sintagmático" e se esta é "uma condição primeira, inerente à linguagem", como explica Benveniste em A forma e o sentido na linguagem (2006a, p. 230231), então o agenciamento sintagmático é ponto nodal para a instauração da significaçáo, seja no discurso ordinário seja no poético. Parece-nos que o mecanismo geral que caracteriza o funcionamento do agenciamento sintagmático pode ser extensível à compreensão do seu mecanismo específico no discurso poético. Nesses termos, compreendemos a afirmação de Benveniste (2006a, p. 221) de que "tudo o que se pode esclarecer no estudo da linguagem ordinária será de proveito, diretamente ou não, para a compreensão da linguagem poética também".

Enfim, consideramos que o "agenciamento sintagmático" é apenas 
um - embora um dos mais determinantes - dentre os "procedimentos pelos quais o poeta organiza/assegura a expressão disso que ele quer comunicar, isto é, de sua emoção" (Env.14, fo 3). Por isso, o estudo do discurso poético envolve o estudo da "poesia mais um certo poeta, já que cada poeta tem sua língua poética" (Env. 21, fo2). De fato, a "linguística da linguagem poética" é, sem dúvida, como nos diz Laplantine (2009, p.37), uma "linguística do específico".

\section{Referências}

ADAM, Jean-Michel. Les problèmes du discours poétique selon Benveniste. Semen, Revue de sémio-linguistique des textes et discours, n. 33, ed. temática (Les notes manuscrites de Benveniste sur la langue de Baudelaire), 2012.

BENVENISTE, Émile. A forma e o sentido na linguagem. In:

Problemas de Linguística Geral II. 2. ed. Campinas, SP: Pontes Editores, 2006a.

. Esta linguagem que faz história. In: Problemas de Linguística Geral II. 2. ed. Campinas, SP: Pontes Editores, 2006b.

FENOGLIO, Irène. Manuscritos de linguistas e genética textual. Quais os desafios para as ciências da linguagem? Exemplo dos "papéis" de Benveniste. In: FLORES, Valdir do Nascimento; GALINDEZ, Verónica; ROSÁRIO, Heloísa Monteiro (Org.). Émile Benveniste: a gênese de um pensamento. Brasília: Editora Universidade de Brasília, 2019a.

- Gênese do gesto linguístico: uma complexidade heurística. In: [FLORES, Valdir do Nascimento; GALINDEZ, Verónica; ROSÁRIO, Heloísa Monteiro (Org.). Émile Benveniste: a gênese de um pensamento. Brasília: Editora Universidade de Brasília, 2019b.

. Émile Benveniste: autor de uma pesquisa inacabada sobre "O discurso poético" e náo de um "Baudelaire". In: FLORES, Valdir do Nascimento; GALINDEZ, Verónica; ROSÁRIO, Heloísa Monteiro (Org.). Émile Benveniste: a gênese de um pensamento. Brasília: Editora Universidade de Brasília, 2019c.

FLORES, Valdir do Nascimento. Introduçáo à teoria enunciativa de Benveniste. São Paulo: Parábola, 2013.

LAPLANTINE, Chloé. Émile Benveniste: poétique de la théorie. 
Publication et transcription des mauscrits inédits d'une poétique de Baudelaire. Thèse de Doctorat sous la direction de Gérard Dessons. Université Paris 8 - Vincennes, Saint-Denis, 2008.

. La poétique d'Émile Benveniste. In: MARTIN, Serge. Émile Benveniste: pour vivre langage. Essais pour la poétique. Mont-de-Laval: L'Atelier du Grand Tétras, 2009. . Émile Benveniste: em direção a uma poética do discurso (Entrevista realizada por Valdir N. Flores e Marlene Teixeira). Calidoscópio, São Leopoldo, vol. 11, n. 2, p. 222-225, maio/ago. 2013.

ONO, Aya. La notion d'enonciation chez Émile Benveniste. Limoges: Lambert-Lucas, 2007.

VIER, Sabrina. Quando a linguística encontra a linguagem: da escrita de Émile Benveniste presente no Dossiê Baudelaire ao estudo semiológico de uma obra literária. 2016. 176 p. Tese (Doutorado em Linguística Aplicada). Programa de Pós-Graduação em Linguística Aplicada, Universidade do Vale do Rio dos Sinos (UNISINOS), São Leopoldo, 2016.

. "Os perfumes, as cores, os sons se correspondem": Benveniste e a busca pela imagem criativa em Baudelaire. Desenredo, Revista do Programa de Pós-Graduação em Letras da Universidade de Passo Fundo, v. 14, n. 3, p. 515-540, set./dez. 2018. 